\title{
Planning of physical load of annual cycle of students', practicing cyclic kinds of sports, training
}

\author{
Nagovitsyn R.S., Volkov P.B., Miroshnichenko A.A. \\ Glazov State Pedagogical Institute, Russia
}

\begin{abstract}
Purpose:

to offer the variant of physical load's distribution in annual cycle of students', practicing cyclic kinds of sports training.

Material: $\quad$ in the research pedagogic HEE students, specializing in skiing and light athletic participated $(n=18-$ boys, $n=8$ -girls, age - 18-23 years). The students were divided into two groups: experimental and control.

Results: $\quad$ by comparison we determined the following: volume and intensity of physical load in micro-cycle and macro-cycle; indicators of cyclic load's distribution in year plan of students' training. In cyclic group of skiers we used the method of standard-interval and alternative exercises. I.e exercises of one load are fulfilled repeatedly. Other method implies variable, increasing or decreasing physical load. Cyclic load, fulfilled at heart beats rate of 160-190 bpm, accented on intensity, prevails. The main requirement is: fulfillment of movements with maximal quickness. In group of light athletic sportsmen the method of standard - continuous exercises, implying moderate intensity, was used For example: standard current exercises - passing distance of $3 \mathrm{~km}, 5 \mathrm{~km}$ or $10 \mathrm{~km}$. Cyclic load, fulfilled at heart beats rate of 140-160 bpm, accented on volume.

Conclusions: In cyclic load of light athletic group aerobic character of work prevails. In cyclic load of skiers' group mixed and anaerobic character of work prevails.

Keywords: $\quad$ students sport, physical load, physical training, anaerobic, training cycles.
\end{abstract}

\section{Introduction}

Demand in physical loads' planning in students', practicing cyclic kinds of sports, annual training cycle is quite an evident fact. Such plan facilitates motivation for trainings [14]; regulator of functional training [15]; current, intermediate and final control of physical fitness $[2,27]$.

In some works it is offered to plan physical load, basing on systemic approach $[1,8,20]$. Such approach envisages finding of main systemic factor and location of hierarchic sub-systems around it. Systemic factors can be: biochemical and physiological principles of sport training [3, 31, 32]; adaptation of organism to physical loads [19, 35]; psycho-emotional changes under influence of physical load [45, 46, 38]. Hierarchic sub-systems' levels are presented by the following indicators: level of physical qualities [6, 41]; energy supply of athlete's muscular functioning $[9,36]$; stages of athlete's training $[13,28]$.

For achievement high sport results in cyclic kinds of sports several years of tensed work and continuous training are required. In this aspect clear planning of training process, considering many factors, is very important.

Considering heterogeneity of systemizing factors' and hierarchic subsystems levels' definitions, different variants are offered in planning physical loads. This fact points at complexity of physical loads' distribution in annual plan of pedagogic HEE students' training.

Other authors point that load value is the main parameter of training impact on athlete's organism. The higher is load the more is organism's fatigue and changes in his functional systems [12]. Duration of work in the state of evident fatigue shall not be so long that it could negatively influence on athlete's technical fitness and his psychic state [2, 40]. It is purposeful to practice trainings with high load after every 2 days. After high load it is necessary to conduct training with low load [6]. In other works it is noted that it is necessary to consider risk factors for reduction of traumatism [30, 42].

It is also necessary to consider that students have to combine academic and leisure activity. They try to demonstrate their abilities maximally with extreme energy consumptions of organism. Periodical missing of trainings neutralize quick effect of physical load. Abnormal weather conditions (for skiing, light athletic) in Central Russia do not facilitate increment of sport indicators.

The fundamental principle of training process's planning is sustaining of optimal coincidence of training loads and student's potentials. Mechanical increasing of training loads' volume and intensity results in failure of organism's adaptation mechanisms.

Analysis of scientific-methodic literature showed that in distribution of cyclic loads in students sport training plans do not change. It reduces the results of work on increasing athlete's workability. Specialists too often base on their personal experience and pay little attention to scientific-methodic works and scientifically based theories of athletes' training [5, 24, 25].

Recent years traditional approaches to training process's building have already lost their value. They do not satisfy requirements to students' training. In this connection, it is necessary to find new ways for training process's realization and effectiveness' increasing.

Hypothesis: it is assumed that in distribution of physical load in annual plan of pedagogic HEE students' training plan (cyclic kinds of sports) it is necessary to base on specificities of students' day regime as well as to concentrate attention on mixed and mixed and anaerobic character of work in annual cycle.

The purpose of the research is to offer the variant of physical load's distribution in annual cycle of students', practicing cyclic kinds of sports training. 


\section{Material and methods}

Participants: in the research pedagogic HEE students, specializing in skiing and light athletic participated $(n=18$ - boys, $n=8$-girls, age - 18 -23 years). The students were divided into two groups: experimental and control (EG and CG).

Organization of the research: realization of experimental program was fulfilled as per the following algorithm:

- In experimental (EG) and control (CG) the quantity of training classes was equal;

- The trainings were conducted in equal climatic conditions, on standard training and competition tracks;

- Students had opportunity to participate in different level competitions;

In experimental group students fulfilled exercises oriented on quickness. In control group trainings were of moderate intensity.

In the research the following methods were applied: pedagogic observation; standard exercises; pedagogic control over training process (operative, current and final); interviewing.

In group of skiers the method of standard-interval and alternative exercises was chosen. The first method implied repeated exercises -one and the same load is used repeatedly. The second method means variable (with increasing or reducing physical load) exercises. Time intervals for rest are different. Cyclic load at heart beats rate (HBR) of 160-190 bpm, accented on intensity (see table 1) prevailed. The main requirement was to fulfill movements with maximal quickness.

In light athletic group we used method of standardcontinuous exercise, oriented on moderate intensity. For example standard exercise - passing of $3 \mathrm{~km}, 5 \mathrm{~km}$ or 10 km distance. Cyclic load at HBR 140-160 bpm, accented on load volume, prevails (see table 2 ).

Assessment of physical loads' influence on studentsathletes' organism permits to ensure control of functional changes' dynamic and find training process's effectiveness. The work at sub-extreme or extreme physical loads was not practiced in training groups.

Differences in cyclic load's planning are recommended only for methods of exercises' usage.

Planning of cyclic load in annual plan of skiers and light athletic sportsmen is presented in summary table (see table 3 and fig. 3).

Micro-cycle in skiers' group in preparatory period is as follows:

In the first day of micro-cycle (after one day rest) skiers fulfilled loads for quickness at short distances by repeated training method: eight accelerations at 200 meters' distance by simultaneous, two-step skate stroke at maximal or sum-maximal temp. After every acceleration cardio-vascular system of a skier is controlled. The rest shall be passive. Before the next exercise heart beats rate restored up to $120 \mathrm{bpm}$. Such kind of load permits to raise the threshold of anaerobic metabolism (TAM) and increase skiing speed.
In second day skiers fulfilled durable power work at gentle and average steepness distance. Alternative method of training was used. By the end of every segment of distance HBR was within 170-180 bpm, i.e. in zone of higher power.

Such character of exercises will ensure for skiers successful passing of different steepness ascents and further quick restoration in the process of distance passing in competition period.

In third and fifth days of micro-cycle the load was planned in the following way: a) in the first half of training - standard-interval exercises for quickness; b) in the second half - even classic classes (moderate loads).

In forth day of training micro-cycle skiers fulfilled exercises of interval method, oriented on speed-power on gentle steepness distances. After exercises athletes' HBR was 180-190 bpm. Under coach's control skiers reduced HBR up to $120 \mathrm{bpm}$. Such kind of load facilitates rising of TAM and maximal oxygen consumption (MOC).

In sixth day of micro-cycle (before the day of passive rest) athletes underwent durable aerobic loads of moderate and low intensity on rugged terrain with pulse of 140-160 bpm. Such character of loads permits for skiers' organism to restore and release fatigue, accumulated during all micro-cycle.

Micro-cycle in preparatory period in group of students, practicing light athletic and sport tourism implies:

In first day (after rest day) students fulfilled cyclic work (standard-continuous exercises) - $15 \mathrm{~km}$ run at moderate speed and HBR $160 \mathrm{bpm}$. Such kind of load permits to increase special (speed) endurance of light athletic sportsmen.

In second day students fulfilled long-term speedpower work on plain terrain: 200 meters and 400 meters run at maximal speed (HBR 180-190 bpm), 800 meter run at moderate speed (HBR 160-170 bpm); 4 accelerations at distance segment of (HBR 170-180 bpm); 1500 meters' run (HBR 150-160 bpm).

Non-uniform run permits for athletes' to adapt to competition rhythm on competition distances.

In third and fifth days of micro-cycle load planning was as follows: a) in first half of training- uniform run (HBR $150 \mathrm{bpm}$ ); b) in second half of training - exercises of speed-power orientation: running upward (HBR 170 bpm).

In forth day of training micro-cycle students fulfilled cyclic work on gentle and moderate steepness terrain: 8-10 ascents on 200 meters' distance with HBR $160-170$ bpm).

In sixth day of micro-cycle (before the day of passive rest) athletes fulfilled cyclic work - standard-continuous exercises: $10 \mathrm{~km}$ distance run at moderate speed (HBR $160 \mathrm{bpm})$.

Statistical analysis: the research results were processed in Excel program. For comparative analysis of physical load distribution's indicators in annual plan of skiers' and light athletes' training we built some diagrams. 


\section{Results}

Analysis of table 1 indicators showed the following (see fig. 1):

- In $1^{\text {st }}$ zone (work with moderate power) $40 \%$ from total volume of cyclic load in annual plan were realized;

- In $2^{\text {nd }}$ zone (work with high power) $50 \%$ from total volume of cyclic load in annual plan were realized;

- In $3^{\text {rd }}$ zone (work sub-maximal power) $60 \%$ from total volume of cyclic load in annual plan were realized;

- In $4^{\text {th }}$ zone (work with maximal power) $70 \%$ from total volume of cyclic load in annual plan were realized.

Analysis of table 2 indicators showed the following (see fig. 1):

- In $1^{\text {st }}$ zone (work with moderate power) $70 \%$ from total volume of cyclic load in annual plan were realized;

- In $2^{\text {nd }}$ zone (work with high power) $80 \%$ from total volume of cyclic load in annual plan were realized;

- In $3^{\text {rd }}$ zone (work sub-maximal power) $40 \%$ from total volume of cyclic load in annual plan were realized;

- In $4^{\text {th }}$ zone (work with maximal power) $30 \%$ from total volume of cyclic load in annual plan were realized.

Comparative analysis of physical load's distribution indicators in annual training plan of skiers and light athletes showed the following:

Table 1. Distribution of cyclic exercises in annual plan of skiers' training

\begin{tabular}{|c|c|c|c|c|}
\hline Description & $\begin{array}{l}\text { Character of } \\
\text { load }\end{array}$ & HBR, bpm & Months & $\begin{array}{l}\text { Volume of } \\
\text { training work in } \\
\text { respect to total } \\
\text { load volume, \% }\end{array}$ \\
\hline $\begin{array}{l}1000 \text { m., } 1500 \text { m., } 3000 \text { m., } \\
5000 \text { m, } 10000 \text { m., } 15000 \text { m. } \\
\text { skiing (free style) }\end{array}$ & aerobic & $150-160 \mathrm{bpm}$ & $\begin{array}{l}\text { November, December, } \\
\text { January, March, April }\end{array}$ & 50 \\
\hline $\begin{array}{l}1000 \text { m., } 1500 \text { m., } 3000 \text { m., } \\
5000 \text { m, } 10000 \text { m., } 15000 \text { m. } \\
\text { skiing (classic style) }\end{array}$ & aerobic & $140-150 \mathrm{bpm}$ & $\begin{array}{l}\text { November, December, } \\
\text { January, March, April }\end{array}$ & 40 \\
\hline $\begin{array}{l}\text { Skiing on plain terrain with } \\
\text { acceleration }\end{array}$ & $\begin{array}{l}\text { aerobic - an- } \\
\text { aerobic }\end{array}$ & $160-170$ bpm & $\begin{array}{l}\text { November, December, } \\
\text { January, March, April }\end{array}$ & 60 \\
\hline $\begin{array}{l}\text { Skiing with ascending, with } \\
\text { acceleration }\end{array}$ & anaerobic & $170-180 \mathrm{bpm}$ & $\begin{array}{l}\text { November, December, } \\
\text { January, March, April }\end{array}$ & 60 \\
\hline $\begin{array}{l}\text { Moving ob ski-rollers, } \\
\text { distance up to } 10000 \mathrm{~m}\end{array}$ & aerobic & $150-160 \mathrm{bpm}$ & May - October & 70 \\
\hline
\end{tabular}

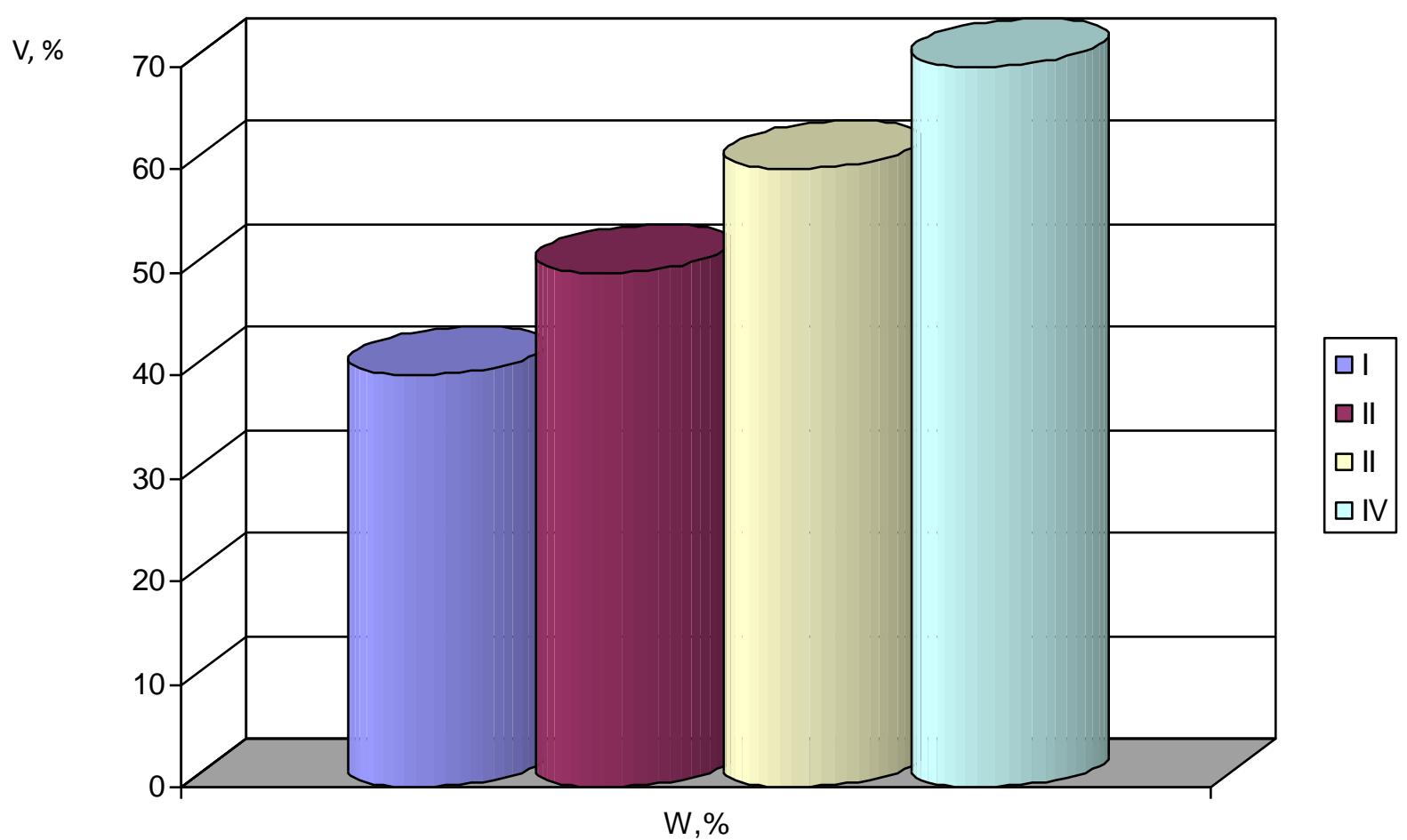

Fig. 1. Distribution of physical load in skiers' annual training plan: I, II, III, IV - zones of work; V - volume of cyclic load; I zone - work with moderate power; II zone - work with high power; III zone - work with sub-maximal power; IV zone - work with maximal power; $\mathrm{W}, \%$ - volume of training work in respect to total load volume. 
- In I zone (work with moderate power) in skiing load was realized within $40 \%$ from total volume of cyclic load. In light athletic load was realized up to $70 \%$ from total volume of cyclic load. The difference in indicators of physical load's distribution in annual plan was 30\%;

- In II zone (work with high power) in skiing load was realized up to $50 \%$ from total volume of cyclic load. In light athletic load was realized up to $80 \%$ from total volume of cyclic load. The difference in indicators of physical load's distribution in annual plan was 30\%;

- In III zone - work with sub-maximal power - in skiing load was realized within $60 \%$ from total volume of cyclic load. In light athletic load was realized up to $40 \%$ from total volume of cyclic load. The difference in indicators of physical load's distribution in annual plan was 20\%;

- In IV zone - work with maximal power - in skiing load was realized within $70 \%$ from total volume of cyclic load. In light athletic load was realized up to $30 \%$ from total volume of cyclic load. The difference in indicators of physical load's distribution in annual plan was $40 \%$.

Comparison of physical load's distribution indicators in annual training plan of skiers and light athletes showed that skiers fulfilled intensive physical work with prevalence of speed-power qualities. In case of light athletes - speed-endurance prevailed.

Increase of intensity in training work formed a foundation for students' successes on sprinter distances: 100 meters' run in light athletic; skiing sprint by classic or skating-skiing style.

The main methods of quickness training are as follows: repeated method of strictly controlled exercise, game method and competition. The pauses between repeated fulfillments of exercises shall ensure relatively complete restoration.

Methodic specificities of physical load's distribution in the structure of annual training cycle are as follows:

Table 2. Distribution of cyclic exercises in annual plan of middle distance light athletes' training

\begin{tabular}{|c|c|c|c|c|}
\hline Description of working zone & $\begin{array}{l}\text { Dozing of physical } \\
\text { load }\end{array}$ & Time & Months & $\begin{array}{l}\text { Volume of training } \\
\text { work in respect to } \\
\text { total load volume, \% }\end{array}$ \\
\hline $\begin{array}{l}\text { I zone - work with moderate } \\
\text { power }\end{array}$ & $\begin{array}{l}\text { HBR - up to } 140 \\
\text { bpm }\end{array}$ & 120 minutes & All year round & 70 \\
\hline Il zone - work with high & $\begin{array}{l}\text { HBR - up to } 140- \\
160 \mathrm{bpm}\end{array}$ & 120 minutes & All year round & 80 \\
\hline $\begin{array}{l}\text { Ill zone - work with sub- } \\
\text { maximal power }\end{array}$ & $\begin{array}{l}\text { HBR - up to } 160- \\
180 \text { bpm }\end{array}$ & 90 minutes & $\begin{array}{l}\text { November, Decem- } \\
\text { ber, January, March, } \\
\text { April }\end{array}$ & 40 \\
\hline $\begin{array}{l}\text { IV zone - work with maximal } \\
\text { power }\end{array}$ & $\begin{array}{l}\text { HBR - up to } 180- \\
190 \text { bpm }\end{array}$ & 60 minutes & $\begin{array}{l}\text { November, } \\
\text { December, January, } \\
\text { March, April }\end{array}$ & 30 \\
\hline
\end{tabular}

$\mathrm{V}, \%$

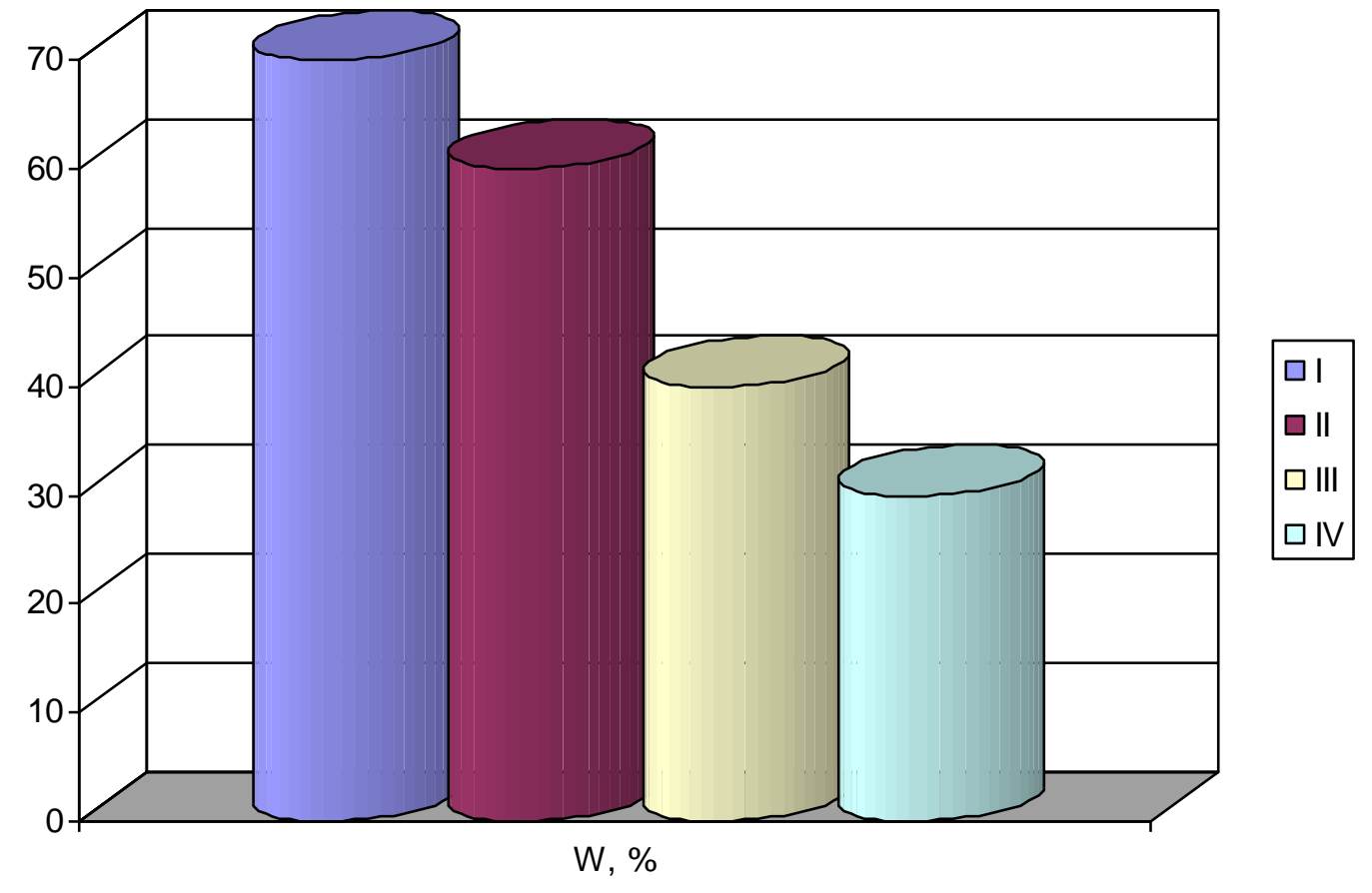

Fig. 2. Distribution of physical load in light athletic sportsmen's annual training plan: I, II, III, IV - zones of work; V volume of cyclic load; I zone - work with moderate power; II zone - work with high power; III zone - work with submaximal power; IV zone - work with maximal power; W, \% - volume of training work in respect to total load volume. 
increase of total quantity of trainings, significant increase of special aerobic or anaerobic loads' volume and increase of quantity of competitions.

Increase of working volume for speed created pre-conditions for success in skiing and light athletic performances, which require speed endurance: middle distances' run, 3 and $5 \mathrm{~km}$ skiing.

The main method of speed endurance training is change of load's intensity in continuous or interval work. The method of alternative load implies change of load intensity in continuous or interval work (HBR from $170-180 \mathrm{bpm}$ to $140 \mathrm{bpm}$ in low-intensity part). Change of intensity facilitates perfection of quickness and simultaneous re-construction of all physiological function to new level.

Let us compare indicators of physical load's distribution in group of students, practicing cyclic kinds of sports.

Analysis of compared results showed the following:

- In skiers' annual training plan, in cyclic load the method of standard-interval and alternative exercise was chosen. It implies repeated fulfillment of exercises with one and the same load. Interval method implies fulfillment of exercises with variable (increasing or decreasing load) character. Different rest intervals were included between repetitions of exercises. Cyclic load at HBR 160-190 bpm, accented on intensity prevails. The main requirement is to fulfill movements with maximal quickness.

- In light athletic group the method of standard continuous exercise prevailed. It implied moderate intensity of cyclic load. For example, it can be standard continuous exercise - passing $3 \mathrm{~km}, 5 \mathrm{~km}$ and $10 \mathrm{~km}$ distances. Cyclic load at HBR 140-160 bpm, accented on load volume, prevails.

\section{Discussion}

In distribution of cyclic load in annual training cycle we came from the following:

- Annual training cycle stipulates the presence of two rather long term competition periods. It obliged athletes to sustain "sport form” for long time [14, 37];

- This factor reflects in physical and psycho-emotional state of organism [21]. With it, athletes' physical loads are so high that they could, sometimes, cause failure of

Table 3. Combined table of physical load's distribution in annual training plan of skiers and light athletes

\begin{tabular}{|c|c|c|c|}
\hline Description of working zone & $\begin{array}{l}\text { Dozing of physical } \\
\text { load }\end{array}$ & $\begin{array}{l}\text { Skiers } \\
\text { Volume of training } \\
\text { work in respect to } \\
\text { total load volume, \% }\end{array}$ & $\begin{array}{l}\text { Light athletes } \\
\text { Volume of training } \\
\text { work in respect to total } \\
\text { load volume, \% }\end{array}$ \\
\hline I zone - work with moderate power & HBR - up to $140 \mathrm{bpm}$ & 40 & 70 \\
\hline Il zone - work with high & $\begin{array}{l}\mathrm{HBR}-\text { up to } 140-160 \\
\mathrm{bpm}\end{array}$ & 50 & 80 \\
\hline $\begin{array}{l}\text { III zone - work with sub-maximal } \\
\text { power }\end{array}$ & $\begin{array}{l}\text { HBR - up to } 160-180 \\
\text { bpm }\end{array}$ & 60 & 40 \\
\hline IV zone - work with maximal power & $\begin{array}{l}\text { HBR - up to } 180-190 \\
\text { bpm }\end{array}$ & 70 & 30 \\
\hline
\end{tabular}

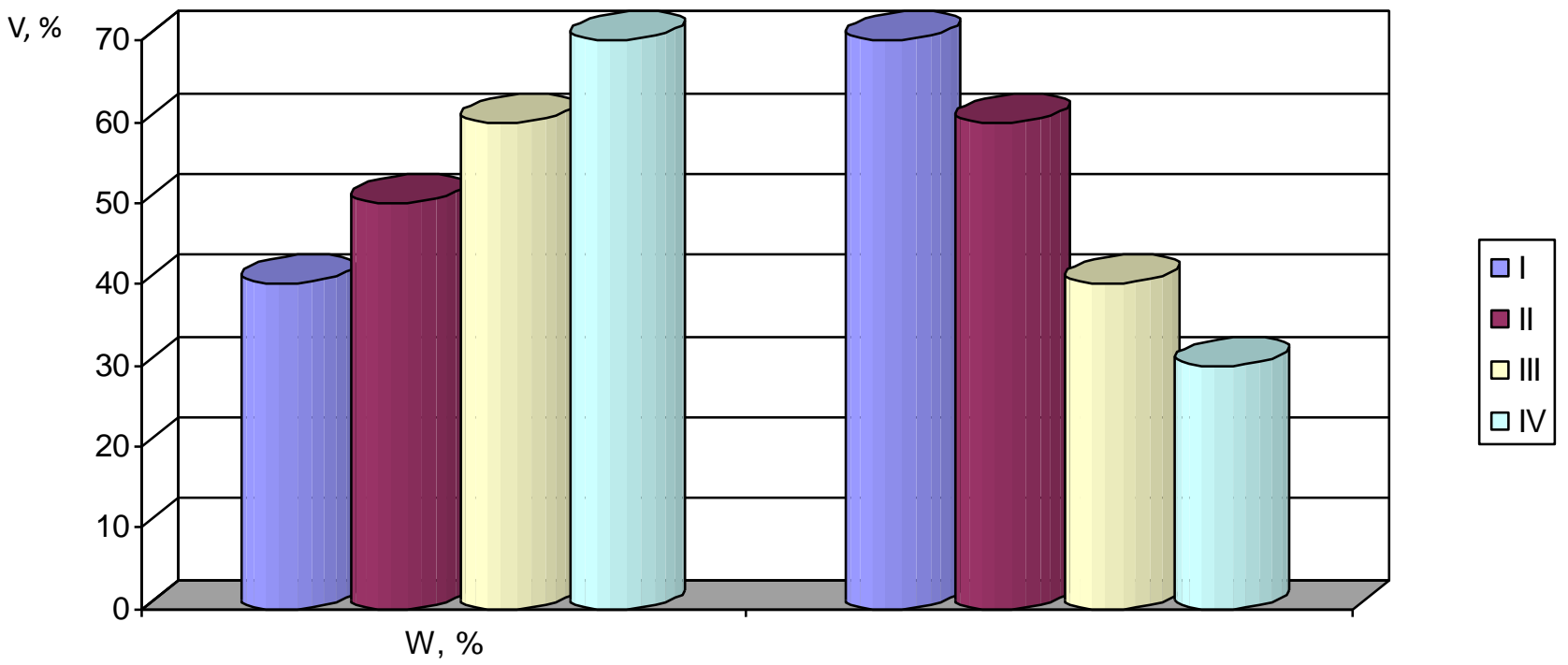

Fig. 3. Distribution of physical load in light athletic sportsmen's and skiers' annual training plan: I, II, III, IV - zones of work; V - volume of cyclic load; I zone - work with moderate power; II zone - work with high power; III zone - work with sub-maximal power; IV zone - work with maximal power; W, \% - volume of training work in respect to total load volume. 
adaptation.

In this connection it is necessary to find new ways of rationalization and increase of effectiveness of cyclic loads' distribution for students. It was found that in distribution of cyclic load training plans are not changed. It neutralizes results of work on athlete's workability training. That is why we offered two variants for training of students, practicing cyclic kinds of sports.

Training processes and distribution of cyclic load in annual training cycle of students are rather complex. For high sport results several years of intensive work and continuous training are required, in the process of which athlete acquires vitally important physical qualities [25]. The fundamental principle in cyclic load's planning in annual cycle of students' training is sustaining of optimal correspondence between training loads and student's potentials.

In training process with progressing (experimental group) and regressing (control group) physical load we tried to avoid mechanical increase of loads' volume, which can cause adaptation failure. Such approach coincides with other study [33]. At certain level further increase of main training loads is possible only at the account of training time increasing [39].

Athletes' training in cyclic kinds of sports is characterized by extreme loads, oriented on simultaneous development of endurance and quickness [6, 26, 29]. In our study combining of differently oriented loads for training of the mentioned qualities requires from athlete high aerobic-anaerobic potentials. Such conclusion concords with results of other research: functioning of all organism systems in appropriate working regimes in training and competition processes [11, 43].

There is one more important factor in cyclic load's planning: with increase of volume of the fulfilled work, its intensity reduces; with reduction of work volume intensity increases. Correlation of volume and intensity in cyclic load's distribution is a criterion of the process and result of athlete's and specialist's work.

\section{Conclusions}

Thus, in our study we compared indicators of cyclic load's distribution in annual training plan of students.

In cyclic work of light athletic groups aerobic character of work prevails in annual training cycle.

In cyclic work of skiers' groups mixed and anaerobic character of work prevails in annual training cycle.

\section{Acknowledgements}

The publication has been prepared in the frames of scientific project №16-16-18003.

\section{Conflict of interests}

The authors declare that there is no conflict of interests.

\section{References}

1. Abalian AG, Lebedev MM, Lebedeva MA. Osobennosti planirovaniia trenirovochnykh nagruzok v podgotovitel'nom periode godichnogo cikla podgotovki biatlonistok olimpijskogo i paralimpijskogo sporta [Planning of training loads in preparatory period of annual cycle of Olympic and Para-Olympic biathlon sportswomen]. Uchenye zapiski universiteta im. P.F. Lesgafta, 2016; 3:23-26. (in Russian)

2. Bagin NA. Effektivnost' trenirovochnykh nagruzok i ikh korrekciia $\mathrm{V}$ trenirovochnom processe lyzhnikovgonshchikov [Effectiveness of training loads and their correction in skiers' training]. Teoriia i praktika fizicheskoj kul'tury; 2010; 5: 13-15. (in Russian)

3. Volkov MI. Biokhimicheskie $i$ fiziologicheskie osnovy sportivnoj trenirovki [Biochemical and physiological principles of sport training]. Cheboksary: Salika; 2010. (in Russian)

4. Butin IM. Lyzhnyj sport [Skiing], Moscow: Academy; 2000. (in Russian)

5. Verkhoshanskij IuV. Osnovy special'noj fizicheskoj podgotovki atletov [Principles of athletes' special physical training]. Moscow: Physical Culture and Sports; 1988. (in Russian)

6. Vlasov NG. Razvitie special'noj vynoslivosti kvalificirovannykh lyzhnikov-gonshchikov na osnove predel'nykh myshechnykh nagruzok, vypolniaemykh povtornym metodom $v$ godichnom cikle podgotovki. Kand. Diss. [Training of elite skiers' special endurance on the base of extreme muscular loads, fulfilled by repeated method in annual training cycle. Cand. Diss.], Moscow; 2008. (in Russian)

7. Vorob'ev AN. Trenirovka, rabotosposobnost', reabilitaciia [Training, workability and rehabilitation]. Moscow: Physical Culture and Sports; 1989. (in Russian)

8. Volkov PB. Planirovanie uchebno-trenirovochnogo processa v podgotovitel'nyj period futbolistov komandy masterov [Planning of training processin preparatory period of elite football palyers]. XI Mezhdunarodnaia nauchnoprakticheskaia konferenciia "Nauka segodnia: teoriia, praktika, innovacii”, 2016, Moskva [XI International scientific-practical conference "Science to-day: theory, practice, innovations”, 2016, Moscow\}. Moscow; 2016. P. 181-187. (in Russian)

9. Volkov PB. Energoobespechenie myshechnoj deiatel'nosti atleta pri vypolnenii klassicheskikh uprazhnenij: ryvok i tolchok v girevom sporte [Energy supply of athlete's muscular functioning in fulfillment of classic exercises: jerk and push in weight lifting]. Vserossijskaia zaochnaia nauchnaia konferenciia "Fiziologiia cheloveka", Cheboksary, 2016 [All Russian correspondence scientific conference "Human physiology”, Cheboksary, 2016], Cheboksary; 2016; 33-36. (in Russian)

10.Volkov PB. Assessment of the quality of work and training of teachers and students during the reorganization of the educational institution by merger in a scientific-educational cluster. Modern European Researches; 2016; 5: 124 -131.

11.Golovachev AI, Kolykhmatov VI. Postroenie trenirovochnogo processa, napravlennogo na razvitie special'noj vynoslivosti lyzhnikov-gonshchikov vysokoj kvalifikacii, specializiruiushchikhsia v sprinterskikh vidakh gonok [Building of training process, directed on elite sprinter skiers' special endurance training]. Vestnik sportivnoj nauki, 2014; 5: 7-12. (in Russian)

12.Grigor'eva IV, Volkova EG, Vodolazov IuS. Fizicheskaia kul'tura. Osnovy sportivnoj trenirovki [Physical culture. Principles of sport training], Voronezh; 2012. (in Russian)

13.Kaminskij IuM. Usloviia povysheniia rabotosposobnosti lyzhnikov-sprinterov v sorevnovatel'noj deiatel'nosti 
[Conditions for workability rising of sprinter skiers in competition activity]. Gumanitarnye nauki i obrazovanie, 2014;1:28-32. (in Russian)

14.Kejno AIu, Il'inykh ES, Fetisov AM. Teoreticheskie osnovy mnogoletnego planirovaniia trenirovki [Theoretical principles of many years training planning]. Sportivnyj vestnik, 2003; 2: 31-36. (in Russian)

15.Kiz'ko AP. Sovershenstvovanie sistemy upravleniia funkcional'noj podgotovkoj atletov na osnove prichinnosledstvennykh zakonomernostej [Perfection of system, controlling athletes' functional training on the base of cause and effect laws]. Novosibirsk: NSTU; 2009. (in Russian)

16.Kovalenko TG, Moiseeva OA, Ryzhkina MG. Osnovy sportivnoj trenirovki [Principles of sport training]. Volgograd: VSU; 2011. (in Russian)

17.Matveev LP. Obshchaia teoriia sporta i ee prikladnye aspekty [General theory of sports and its applied aspects]. Moscow: Soviet Sport; 2010. (in Russian)

18.Nagovitsyn RS, Vladykina IV, Volkov PB, Tutolmin AV, Sokol'nikova EI. Programmnoe upravlenie sovershenstvovaniem fizicheskoj kul'tury studentov s primeneniem mobil'nykh sredstv [Program control over perfection of students' physical culture with the help of mobile means]. Teoriia i praktika fizicheskoj kul 'tury, 2015;4: 33-35. (in Russian)

19.Nagovitsyn RS, Rassolova E.A., Senator S.Iu., Torbina I.I. Razrabotka veb-portala dlia podgotovki k testirovaniiu po normam GTO [Working out of website for preparation for testing by RWD norms]. Teoriia i praktika fizicheskoj kul'tury, 2016;1: 39-42. (in Russian)

20.Nagovitsyn RS, Rassolova EA, Sokol'nikova EI, Senator SIu, Torbina II. Tekhnologiia sistemnogo razvitiia fizicheskikh kachestv molodezhi na osnove mobil'nogo obucheniia [Technology of youth's physical qualities' systemic development on the base of mobile training]. Teoriia $i$ praktika fizicheskoj kul 'tury, 2015;11: 100-102. (in Russian)

21.Suslov FP, Shepel' SP. Struktura godichnogo sorevnovatel'notrenirovochnogo cikla podgotovki: real'nost' i illiuzii [The structure of annual competition-training cycle: reality and illusions]. Teoriia i praktika fizicheskoj kul'tury, 2009; 9: 5761. (in Russian)

22. Adam M. Gonzalez. Effect of Interset Rest Interval Length on Resistance Exercise Performance and Muscular Adaptation. Department of Health Professions, Hofstra University, Hempstead: New York; 2016.

23.Bompa TO. Periogizacao teoria e metodologia do treinamento [Periodization theory and training methodology]. Sao Paulo: Phorte Editora Ltd.; 2002. (in Portuguese)

24.Zheliazkov C. Osnovi na sportnata trenirovka [Basics of sports training], Sofia: Hera; 2011. (in Bulgaria)

25.Platonov VN. Teoriia i metodika sportivnoj trenirovki [Theory and methodic of sport training]. Kiev: High School; 1984. (in Russian)

26.Aoki K, Kohmura Y, Sakuma K, Koshikawa K, Naito H. Relationships Between Field Tests of Power and Athletic Performance in Track and Field Athletes Specializing in Power Events. Int J Sports Sci Coa. 2015;10(1):133-44.

27.Aragon S, Lapresa D, Arana J, Anguera MT, Garzon B. Tactical behaviour of winning athletes in major championship 1500-m and 5000-m track finals. European Journal of Sport Science. 2016;16(3):279-86.

28.Bolger R, Lyons M, Harrison AJ, Kenny IC. Coaching sprinting: Expert coaches' perception of resistance-based training. Int J Sports Sci Coa. 2016;11(5):746-54.
29.Churchill SM, Trewartha G, Bezodis IN, Salo AIT. Force production during maximal effort bend sprinting: Theory vs reality. Scandinavian Journal of Medicine \& Science in Sports. 2016;26(10):1171-9.

30.Edouard P, Branco P, Alonso JM, Junge A. Methodological quality of the injury surveillance system used in international athletics championships. Journal of Science and Medicine in Sport. 2016;19(12):984-9.

31.Grycmann P, Maszczyk A, Socha T, Golas A, Wilk M, Zajac $\mathrm{T}$, et al. Modelling analysis and prediction of women javelin throw results in the years 1946-2013. Biology of Sport. 2015;32(4):345-50.

32.Guilhem G, Hanon C, Gendreau N, Bonneau D, Guevel A, Chennaoui M. Salivary Hormones Response to Preparation and Pre-competitive Training of World-class Level Athletes. Frontiers in Physiology. 2015;6.

33.Haff GG, Haff EE. Training integration and periodization. In: NSCA's program design, National Strength and Conditioning Assosiation. Hoffman JR ed. Champaign, IL: Human Kinetics; 2012.

34.Harre D. Principles of sports training. Berlin: Sportverlag; 1982.

35.Hebert-Losier K, Zinner C, Platt S, Stoggl T, Holmberg HC. Factors that Influence the Performance of Elite Sprint CrossCountry Skiers. Sports Med. 2017;47(2):319-42.

36.Hegge AM, Myhre K, Welde B, Holmberg HC, Sandbakk O. Are Gender Differences in Upper-Body Power Generated by Elite Cross-Country Skiers Augmented by Increasing the Intensity of Exercise? Plos One. 2015;10(5):50-56.

37.Judge LW, Judge M, Bellar DM, Hunter I, Hoover DL, Broome R. The integration of sport science and coaching: A case study of an American junior record holder in the hammer throw. Int J Sports Sci Coa. 2016;11(3):422-35.

38.Judge LW, Kirkpatrick K, Bolin J, Blom LC, Dieringer S, Bellar D. Understanding the Occupational Stress of Collegiate Track and Field Coaches during the Championship Season. Int J Sports Sci Coa. 2015;10(5):769-82.

39.Kraemer WJ, Haff GC. Roundtable disscussion: periodization of training, Stength \& Conditioning J. 2004;26 (1): 50-53.

40.Lawless FJ, Grobbelaar HW. Sport psychological skills profile of track and field athletes and comparisons between successful and less successful track athletes. South African Journal for Research in Sport Physical Education and Recreation. 2015;37(3):123-42.

41.Losnegard T, Myklebust H, Ehrhardt A, Hallen J. Kinematical analysis of the V2 ski skating technique: A longitudinal study. J Sport Sci. 2017;35(12):1219-27.

42. Opar D, Drezner J, Shield A, Williams M, Webner D, Sennett $\mathrm{B}$, et al. Acute Injuries in Track and Field Athletes A 3-Year Observational Study at the Penn Relays Carnival With Epidemiology and Medical Coverage Implications. Am $J$ Sport Med. 2015;43(4):816-22.

43.Pereira J, Hastie P, Araujo R, Farias C, Rolim R, Mesquita I. A Comparative Study of Students' Track and Field Technical Performance in Sport Education and in a Direct Instruction Approach. J Sport Sci Med. 2015;14(1):118-27.

44.Plisk S, Stone M. Periodization strategies, Strength and Conditioning, 2003; 25:18-37.

45.Willardson JM, Burkett LN. The effect of different rest intervals between sets on volume components and strength gains. J Strength Cond Res, 2008; 22: 146-152.

46.Wilmore JH, Costill DL. Physiology of sport and exercise. Champaign, Illinois: Human Kinetics; 2004. 
Information about the authors:

Nagovitsyn R.S.: http://orcid.org/0000-0003-4471-0875; gto18@mail.ru; Glazov State Pedagogical Institute; Pervomaiskaya Street, 25, Glazov,427620, Russia.

Volkov P.B.: http://orcid.org/0000-0003-0347-3084; pbvolk@mail.ru; Glazov State Pedagogical Institute; Pervomaiskaya Street, 25, Glazov,427620, Russia.

Miroshnichenko A.A.: http://orcid.org/0000-0002-2845-3437; ggpi@mail.ru; Glazov State Pedagogical Institute; Pervomaiskaya Street, 25, Glazov,427620, Russia.

Cite this article as: Nagovitsyn RS, Volkov PB, Miroshnichenko AA. Planning of physical load of annual cycle of students', practicing cyclic kinds of sports, training. Physical education of students, 2017;21(3):126-133. doi:10.15561/20755279.2017.0305

The electronic version of this article is the complete one and can be found online at: http://www.sportedu.org.ua/index.php/PES/issue/archive

This is an Open Access article distributed under the terms of the Creative Commons Attribution License, which permits unrestricted use, distribution, and reproduction in any medium, provided the original work is properly cited (http://creativecommons.org/licenses/by/4.0/deed.en).

Received: 23.04.2017

Accepted: 30.04.2017; Published: 10.05.2017 